\title{
A ELABORAÇÃO DO PLANO DE DESENVOLVIMENTO URBANO INTEGRADO DA REGIÃO METROPOLITANA DA BAIXADA SANTISTA
}

\section{Avanços e desafios}

Oprocesso de contratação, elaboraçãoe implementação dos PDUls, contemplando as soluções de governança do plano, a definição dos instrumentos, os arranjos de gestão e a solução de conflitos de uso e ocupação do solo

Relatório de Pesquisa

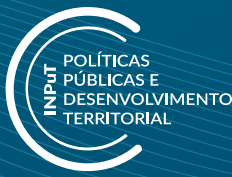





\section{A ELABORAÇÃO DO PLANO DE DESENVOLVIMENTO URBANO INTEGRADO DA REGIÃO METROPOLITANA DA BAIXADA SANTISTA}

Avanços e desafios

Oprocesso de contratação, elaboraçãoe implementação dos PDUls, contemplando as soluções de governança do plano, a definição dos instrumentos, os arranjos de gestão e a solução de conflitos de uso e ocupação do solo

Relatório de Pesquisa

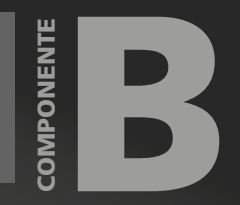




\section{Governo Federal}

Ministério da Economia

Ministro Paulo Guedes

\section{ipea stituroderesususe Econômica Aplicada}

Fundação pública vinculada ao Ministério da Economia, o Ipea fornece suporte técnico e institucional às ações governamentais - possibilitando a formulação de inúmeras políticas públicas e programas de desenvolvimento brasileiros - e disponibiliza, para a sociedade, pesquisas e estudos realizados por seus técnicos.

\section{Presidente}

Carlos von Doellinger

Diretor de Desenvolvimento Institucional Manoel Rodrigues Junior

Diretora de Estudos e Políticas do Estado, das Instituições e da Democracia

Flávia de Holanda Schmidt

Diretor de Estudos e Políticas

Macroeconômicas

José Ronaldo de Castro Souza Júnior

Diretor de Estudos e Políticas Regionais,

Urbanas e Ambientais

Nilo Luiz Saccaro Júnior

Diretor de Estudos e Políticas Setoriais de Inovação

e Infraestrutura

André Tortato Rauen

Diretora de Estudos e Políticas Sociais

Lenita Maria Turchi

Diretor de Estudos e Relações Econômicas

e Políticas Internacionais

Ivan Tiago Machado Oliveira

Assessor-chefe de Imprensa

e Comunicação (substituto)

João Cláudio Garcia Rodrigues Lima

Ouvidoria: http://www.ipea.gov.br/ouvidoria

URL: http://www.ipea.gov.br 


\section{A ELABORAÇÃO DO PLANO DE DESENVOLVIMENTO URBANO INTEGRADO DA REGIÃO METROPOLITANA DA BAIXADA SANTISTA}

Avanços e desafios

Oprocesso decontratação, elaboraçãoe implementação dos PDUls, contemplando as soluções de governança do plano, a definição dos instrumentos, os arranjos de gestão e a solução de conflitos de uso e ocupação do solo

Relatório de Pesquisa
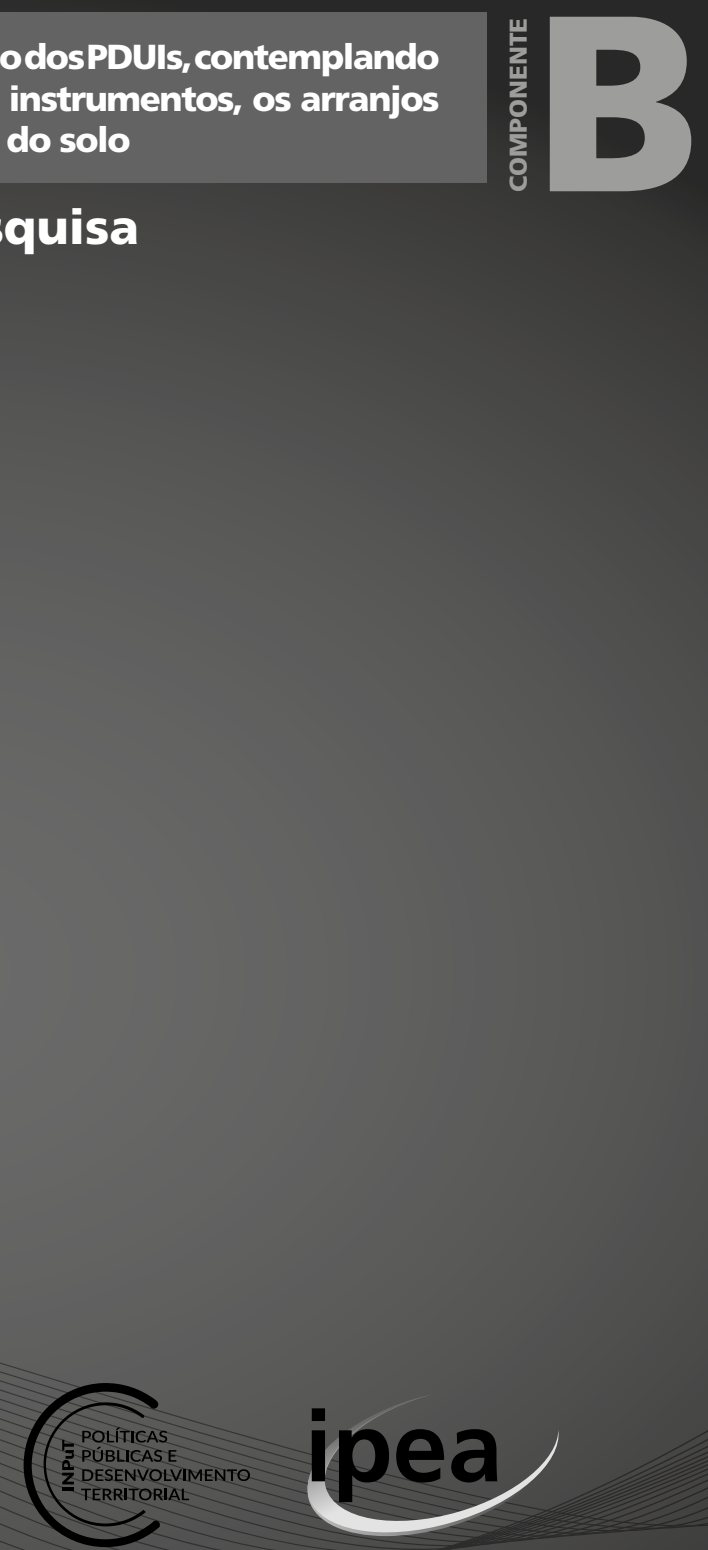

Brasilia, 2021 


\section{COORDENAÇÃO NACIONAL}

\section{Marco Aurélio Costa}

Coordenador nacional do Instituto Nacional de Ciência e Tecnologia (INCT) em Políticas Públicas e Desenvolvimento Territorial (INPuT).

Coordenador da Coordenação de Estudos em Desenvolvimento Urbano (Codur) da Diretoria de Estudos e Políticas Regionais, Urbanas e Ambientais (Dirur) do Ipea. E-mail: <marco.costa@ipea.gov.br>.

\section{COORDENAÇÃO DO PROJETO GOVERNANÇA METROPOLITANA NO BRASIL}

\section{Marco Aurélio Costa}

Coordenador nacional do INCT/INPuT. Coordenador da Codur/Dirur/Ipea.E-mail: <marco.costa@ipea.gov.br>.

\section{Bárbara Oliveira Marguti}

Pesquisadora na Dirur/lpea. E-mail: <barbara.marguti@ipea.gov.br>.

\section{SUPERVISÃO TÉCNICA}

\section{José Marques Carriço}

Arquiteto e urbanista, professor e pesquisador do Programa de Pós-Graduação Stricto Sensu em Direito e do curso de Arquitetura e Urbanismo da Universidade Católica de Santos (UniSantos). Co-líder do grupo de pesquisa Direito Ambiental das Cidades da UniSantos. E-mail: <jose.carrico@ unisantos.br>.

\section{Bárbara Oliveira Marguti}

Pesquisadora na Dirur/|pea. E-mail: <barbara.marguti@ipea.gov.br>.

\section{Luis Gustavo Vieira Martins}

Pesquisador na Dirur/lpea. E-mail: <gustavo.martins@ipea.gov.br>.

\section{Lizandro Lui}

Pesquisador do Subprograma de Pesquisa para o Desenvolvimento Nacional (PNPD) na Dirur/lpea. E-mail: <lizandro.lui@ipea.gov.br>.

\section{Sara Rebello Tavares}

Assistente de pesquisa III do projeto Governança Metropolitana no Brasil do Ipea. E-mail: <sara.tavares@ipea.gov.br>.

\section{REVISÃO TÉCNICA}

\section{Bárbara Oliveira Marguti}

Pesquisadora na Dirur/lpea. E-mail: <barbara.marguti@ipea.gov.br>.

\section{Sara Rebello Tavares}

Assistente de pesquisa III do projeto Governança Metropolitana no Brasil do Ipea. E-mail: <sara.tavares@ipea.gov.br>.

\section{AUTORIA}

\section{Edson Ricardo Saleme}

Professor do curso stricto sensu em direito ambiental internacional da UniSantos e do curso de especialização do Ministério Público do Estado de São Paulo (MP-SP). Co-líder do grupo de pesquisa Direito Ambiental das Cidades da UniSantos. E-mail: <ricasal@unisantos.br>.

\section{José Marques Carriço}

Professor e pesquisador do Programa de Pós-Graduação Stricto Sensu em Direito e do curso de Arquitetura e Urbanismo da UniSantos. Co-líder do grupo de pesquisa Direito Ambiental das Cidades da UniSantos. E-mail: <jose.carrico@unisantos.br>.

\section{Lenimar Gonçalves Rios}

Professora do curso de Arquitetura e Urbanismo da UniSantos. Integrante do grupo de pesquisa Observatório Socioespacial da Baixada Santista (Observa-BS) da UniSantos.E-mail: <lenimar.rios@unisantos.br>.

\section{Mônica Antonia Viana}

Professora dos cursos de Arquitetura e Urbanismo e de Engenharia Ambiental da UniSantos. Líder do grupo de pesquisa Observa-BS/UniSantos. Consultora na área de Planejamento Urbano e Regional e Gestão Ambiental. E-mail: <moviana@unisantos.br>.

\section{DOI: https://dx.doi.org/10.38116/rp-rmbaixadasantista-comp-b}

As publicações do Ipea estão disponíveis para download gratuito nos formatos PDF (todas) e EPUB (livros e periódicos). Acesse: http://www.ipea.gov.br/portal/publicacoes

As opiniões emitidas nesta publicação são de exclusiva e inteira responsabilidade dos autores, não exprimindo, necessariamente, o ponto de vista do Instituto de Pesquisa Econômica Aplicada ou do Ministério da Economia.

É permitida a reprodução deste texto e dos dados nele contidos, desde que citada a fonte. Reproduções para fins comerciais são proibidas. 


\section{SUMÁRIO}

1 INTRODUÇÃO

2 INSTRUMENTOS DE POLÍTICA URBANA NO CONTEXTO DA COOPERAÇÃO INTERFEDERATIVA ............................................9

3 COMPATIBILIZAÇÃO COM OS PLANOS DIRETORES ...........................................................................................14

4 MAPEAMENTO DE CONFLITOS DE USO DO SOLO: IDENTIFICAÇÃO, TIPOLOGIAS E DESAFIOS/SOLUÇÕES ..............................16

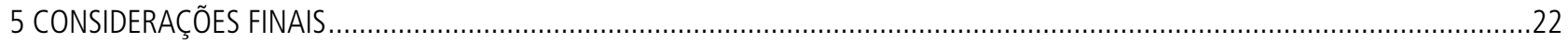

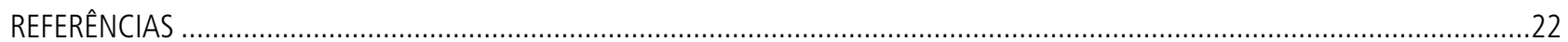





\section{INTRODUÇÃO}

A regiáo metropolitana (RM) da Baixada Santista, localizada na área central do litoral de São Paulo, é resultado de processo de urbanização intensificado pela industrialização do estado. Isso ocorreu após a Segunda Guerra Mundial, com aceleração dos fluxos migratórios internos e externos ao estado.

A RM da Baixada Santista é composta por nove municípios: Santos, São Vicente, Cubatâo, Guarujá, Praia Grande, Bertioga, Mongaguá, Itanhaém e Peruíbe, sendo o primeiro o polo regional e os cinco primeiros, integrantes de área metropolitana com maior nível de integração das funçôes públicas de interesse comum (FPICs). Nessa área, está localizada a sede do Porto de Santos, o mais importante do Brasil e maior porto da América Latina, cujo complexo também compreende os municípios de Guarujá e Cubatão, estabelecendo-se neste último um importante conjunto de indústrias petroquímicas e siderúrgicas.

Após a década de 1960, com a saturação urbana da Ilha de São Vicente, onde se situam as cidades de Santos e São Vicente, fluxos migratórios internos passaram a ocorrer a partir desses dois municípios, inicialmente em direção a Cubatâo e Guarujá, localizados, respectivamente, a norte e a leste da referida ilha. Porém, com o crescimento industrial de Cubatão e a extensão do Porto de Santos para a margem esquerda do estuário, em Guarujá, esses municípios também passaram a apresentar dinâmicas próprias de urbanização, compondo com os dois municípios centrais um todo conurbado.

Naquele período, migrantes que chegavam de outras regióes, para o trabalho nas indústrias de Cubatão e no Porto de Santos, passaram a fixar-se em localizaçóes mais afastadas nas periferias do polo regional, ou em assentamentos precários localizados nos municípios centrais da regiáo, em áreas ambientalmente protegidas e de risco geológico e tecnológico.

A partir da década de 1970, o governo do estado ampliou a ligação rodoviária com o planalto e passou a implantar estrutura rodoviária nos vetores sul e norte da Baixada Santista, facilitando o crescimento da atividade imobiliária vinculada ao turismo balneário. Primeiro, o eixo da SP-55 possibilitou a implantação de uma série de empreendimentos imobiliários de uso ocasional, entre a área central da região e o município de Peruíbe, em seu extremo sul. Posteriormente, com a extensão da SP-55 para o norte - entre o município de Bertioga, então distrito de Santos, e o Litoral Norte -, essa modalidade de empreendimento passou a ocupar a planície litorânea, de forma descontínua (Rios, 2019).

Como resultado desse processo de crescimento periférico, no vetor sul, acelerou-se a urbanização do município de Praia Grande, resultante do desmembramento do território de São Vicente, em 1967. Posteriormente, Mongaguá e Itanhaém também passaram a apresentar intensa produção imobiliária de caráter ocasional, completando processo de conurbação entre o polo e os municípios do sul. Assim, atualmente se observa a conurbação quase integral das áreas urbanas existentes entre Guarujá e Itanhaém, com maior fragmentação das manchas urbanas nos municípios das extremidades (Peruíbe e Bertioga).

Com a Constituição Federal de 1988 (CF/1988), sendo delegada aos estados a criação de regióes metropolitanas, e após a promulgação, em 1989, da Constituição do Estado de Sáo Paulo, ${ }^{1}$ foi institucionalizada a RM da Baixa Santista. Isso ocorreu por meio da Lei Complementar (LC) no 815, de 30 de julho de 1996; tal RM foi a primeira unidade regional desse tipo, a ser criada fora de capital de estado. 
Com a consolidação da regiáo, definiu-se seu arranjo institucional em torno de um tripé composto por conselho, agência e fundo. A própria LC no 815/1996 autorizou a institucionalização do Conselho de Desenvolvimento da Região Metropolitana da Baixada Santista (Condesb), a criação de entidade autárquica, a Agência Metropolitana da Baixada Santista (Agem-BS), e a instituição do Fundo de Desenvolvimento Metropolitano da Baixada Santista (Fundo).

O Condesb é formado por representantes das prefeituras da RM da Baixa Santista e do governo do estado, indicados entre as secretarias que atuam nas funçóes públicas de interesse comum da regiáo. Esse conselho tem caráter normativo e deliberativo, tratando dos assuntos inerentes às FPICs da RM. A participação de seus representantes é paritária entre o conjunto das prefeituras e os representantes do estado. As funçôes públicas de interesse comum da região são definidas pelo próprio Condesb.

Com a finalidade de integrar a organização, o planejamento e a execução das FPIC, a Agem-BS foi criada pela LC Estadual no 853, de 23 de dezembro de 1998, alterada pela LC Estadual no 956, de 28 de maio de 2004. Por meio do Decreto Estadual no 44.127, de 21 de julho de 1999, foi aprovado seu regulamento.

O Decreto Estadual no 42.833, de 28 de janeiro de 1998, regulamentou o Fundo de Desenvolvimento Metropolitano da Baixada Santista, de que trata a LC no ${ }^{\circ} 815 / 1996$. Essa norma foi alterada pelo Decreto Estadual no 56.635, de 1ํㅡㄹ je janeiro de 2011.

Esse arranjo de governança regional garantiu exagerado peso ao governo estadual, com relação aos municípios integrantes e, sobretudo, à sociedade civil, cuja participação no processo de planejamento e gestão das FPICs ainda é incipiente. O próprio Condesb ainda não possui atuação efetiva em importantes campos funcionais, como saneamento, transportes, habitação e uso do solo. Nos dois primeiros casos, ainda é preponderante o papel do governo estadual e das empresas públicas estaduais responsáveis. Nos dois últimos (habitação e uso do solo), a atuação dos municípios - embora leve em consideração o Zoneamento Ecológico-Econômico da Baixada Santista (ZEE-BS) (Sáo Paulo, 2013) aprovado por decreto do governador em 2013 - ainda ocorre de forma descoordenada, em que pese o nível de integração do processo de urbanização.

Com a determinação do art. 1º, da Lei nº 13.089/2015 (Estatuto da Metrópole), no sentido de que as RMs e as aglomeraçôes urbanas elaborassem seu próprio plano de desenvolvimento urbano integrado (PDUI), aprovado mediante lei estadual, a ser posteriormente base dos planos diretores dos municípios formadores da entidade regional, o Condesb, por meio da Agem-BS, intensificou açóes no sentido de elaborar o PDUI da RMBS. A meta era que os PDUIs deveriam se converter em LC estadual até janeiro de 2018. Conforme descrito em Carriço e Saleme (2018), em novembro de 2017, o Condesb aprovou a minuta de projeto de lei complementar (PLC), encaminhando-o ao governo do estado de Sáo Paulo, para apreciação e envio à Assembleia Legislativa do Estado de São Paulo (Alesp).

Contudo, o Estatuto da Metrópole havia sido aprovado dois anos após o governo estadual ter publicado o decreto de regulamentação do ZEE-BS e um ano após a Agem-BS ter concluído o Plano Metropolitano de Desenvolvimento Estratégico (PMDE-BS), em 2014, trazendo a oportunidade de incorporação ao PDUI-BS do macrozoneamento do ZEE-BS e de diretrizes, metas e açóes do PMDE-BS, conforme relatado em Carriço e Saleme (2018).

Com esse pano de fundo, a seguir, apresenta-se um painel acerca da governança da RM da Baixada Santista, no âmbito da quinta etapa do projeto Governança Metropolitana no Brasil, 
com foco em seu componente B (processo de contratação, elaboraçáo e implementação do Plano de Desenvolvimento Urbano Integrado da RM da Baixada Santista). Com essa finalidade, na seção 2 , será discutido o processo de implementação dos instrumentos de política urbana no contexto da cooperaçáo interfederativa, com vistas a dar continuidade ao acompanhamento do processo local de elaboração e implementação do PDUI-BS. Na seção 3, será apresentado o contexto da compatibilização entre esse plano e os planos diretores dos municípios integrantes da regiáo. Na seção 4, será revelado o mapeamento de conflitos de uso do solo, identificando-os e classificando-os por tipologias, além de apontar desafios e soluçóes a partir de estudos de caso. $\mathrm{Na}$ sequência, serão realizadas as consideraçôes finais. As análises e a realização deste relatório foram fruto da parceria de dois grupos de pesquisa da Universidade Católica de Santos (UniSantos), de forma integrada e interdisciplinar: Direito Ambiental de Cidades, do Programa de Pós-Graduação Stricto Sensu em Direito Ambiental e Internacional, e o Observatório Socioespacial da Baixada Santista, do curso de graduação e do Programa de Mestrado em Arquitetura e Urbanismo.

\section{INSTRUMENTOS DE POLÍTICA URBANA NO CONTEXTO DA COOPERAÇÃO INTERFEDERATIVA}

Não houve modificação ou atualização na estrutura institucional e normativa da RM da Baixada Santista, desde o início do processo de elaboração do PDUI-BS, em abril de 2015. Porém, com a publicação do Decreto Estadual no 64.063, de 1o de janeiro de 2019, os conselhos e as agências regionais do estado de Sáo Paulo passaram da esfera da Casa Civil para a Secretaria de Desenvolvimento Regional (SDR) (art. 3o). Outra mudança importante diz respeito ao processo de liquidação da Empresa Paulista de Planejamento Metropolitano S/A (Emplasa), decorrente da aprovaçáo da Lei Estadual no 17.056/2019. Com enorme expertise em planejamento regional, a Emplasa prestava assessoria técnica às agências metropolitanas paulistas e cedia funcionários com grande experiência, para apoio técnico às autarquias metropolitanas. Com a extinçáo da empresa, funcionários que atuaram na criaçáo do PDUI da RM da Baixada Santista foram demitidos, prejudicando o desenvolvimento das atividades previstas na sequência do processo de elaboração do plano, sobretudo no tocante ao Sistema de Informação e Monitoramento e Avaliação da Baixada Santista (Sima-BS).

Quanto ao processo de criação do PDUI-BS, para garantir a gestáo plena da RM da Baixada Santista, de acordo com o disposto no Estatuto da Metrópole, por meio de sua Deliberaçáo no 001/2016, o Condesb "aprovou o Plano de Trabalho que orientou os debates para a elaboração do projeto de lei complementar, incluindo a participação da sociedade civil” (Agem-BS, 2019). Contudo, conforme exposto em Carriço e Saleme (2018), essa participação não garantiu sua inclusão no sistema de governança interfederativa, na condição de componente da instância deliberativa. Todavia, assegurou a participação de representantes da sociedade civil no processo final de concepção do PDUI-BS, em 2017, bem como a continuidade da participação desses representantes na Câmara Temática de Planejamento e Desenvolvimento Econômico da Agem-BS, ao longo de 2018, em quatro frentes definidas no plano de trabalho: i) o acompanhamento do Sima-BS; ii) a criaçáo de regras para acompanhamento do PDUI-BS; iii) a definição de critérios para as áreas de interesse metropolitano; e iv) a formulação de diretrizes para a cartilha do PDUI-BS. Somente essa última tarefa não teve um produto final elaborado, pois dependia da aprovação do plano na Alesp. ${ }^{2}$

2. Relato da professora Mônica Antonia Viana (2019), que participou desse processo representando a UniSantos, no período de setembro de 2017 a dezembro de 2018, na elaboração e no acompanhamento do PDUI-BS, coordenada pela Câmara Temática de Planejamento e Desenvolvimento Econômico. 
A minuta do PLC do PDUI-BS foi concluída em novembro de 2017, conforme processo descrito em Carriço e Saleme (2018), sendo elaborada por meio de processo coordenado pela equipe técnica da Agem-BS, sem contrataçáo de consultoria, a partir de discussáo com a Câmara Temática de Planejamento e Desenvolvimento Econômico.

Também de acordo com a Agem-BS,

em junho de 2016 foi aberta a Plataforma de Trabalho Colaborativa por meio da criaçáo de site específico (hotsite) para garantir informação e transparência ao processo de discussão, além do acompanhamento do Ministério Público. Também no mês de junho de 2016 foi realizada a primeira rodada de cinco oficinas temáticas sobre as Funçôes Públicas de Interesse Comum: Planejamento e Desenvolvimento Econômico, Mobilidade e Logística, Habitação e Desenvolvimento Urbano, Saneamento e Meio Ambiente e ainda Políticas Sociais (Agem-BS, 2019).

Segundo a Agem-BS (2019), "o objetivo foi obter contribuições a serem incorporadas ao conjunto de propostas de forma a consolidar os objetivos, metas e estratégias propostas" no Plano Metropolitano de Desenvolvimento Estratégico da Baixada Santista (PMDE-BS), ${ }^{3}$ assim como "no macrozoneamento da região, oriundo do Zoneamento Econômico e Ecológico (ZEE) e nos Planos Diretores Municipais". ${ }^{4}$

Portanto, a partir de proposta da Agem-BS, a Câmara Temática de Planejamento e Desenvolvimento Econômico deliberou incorporar à minuta do PDUI-BS o PMDE-BS 5 e o macrozoneamento do ZEE da RM da Baixada Santista. Metodologicamente, essa foi a principal decisão da câmara, pois permitiu consolidar objetivos, metas e estratégias propostas no PMDE-BS, utilizando o macrozoneamento recentemente regulamentado pelo ZEE-BS, além dos planos setoriais regionais a serem elaborados e os planos diretores e planos setoriais dos municípios. Na época, a agência sugeriu aperfeiçoamentos na estrutura de governança interfederativa e ajustes de regimentos e formas de participação da sociedade civil, que de fato nunca vieram a ocorrer. Porém, ainda que de forma vaga, a Agem-BS assumiu a necessidade de aperfeiçoar as instâncias de participaçáo da sociedade no processo de criaçáo e deliberação do PDUI-BS.

A Câmara Temática de Planejamento e Desenvolvimento Econômico coordenou reunióes que definiram os eixos estratégicos do PDUI-BS, que devem consubstanciar suas FPICs, sendo esses: $i$ ) planejamento e desenvolvimento econômico; $i$ i) saneamento e meio ambiente; iii) habitação e desenvolvimento urbano; $i v$ ) mobilidade e logística; e $v$ ) políticas sociais. As quatro primeiras já existiam no PMDE-BS; todavia, a quinta FPIC foi criada por reivindicação dos participantes das oficinas.

Conforme a Agem-BS (2019), "entre abril e maio de 2017, foi realizado novo ciclo de oficinas temáticas, agora com a participação da Sociedade Civil organizada”. Após os

3. Segundo a Agem-BS (2019), o PMDE-BS foi elaborado por consultoria especializada, "com a proposta de estabelecer uma visão de futuro para a região". "O estudo incluiu avaliação dos planos, projetos e programas municipais, estaduais e federais existentes e análises das projeções de crescimento econômico e populacional que impactam sobre a infraestrutura urbana (habitação, mobilidade e saneamento básico etc.)". De acordo com essa fonte, "esse plano também fundamentou necessidades induzidas por um ciclo de desenvolvimento econômico baseado nas atividades portuárias, na exploração de petróleo e gás, obras públicas, turismo e construção civil. Consolidou políticas municipais, estaduais e federais, por meio da apresentação de 32 orientações de planejamento, 23 projetos estruturantes, 47 ações e 77 programas públicos e privados de desenvolvimento para os nove municípios da região, apontando para um horizonte até 2030" 4. 0 macrozoneamento do ZEE da RM da Baixada Santista foi regulamentado pelo Decreto Estadual no 58.996, de 25 de março de 2013 , após quinze anos de discussões, que envolveram sua compatibilização com os zoneamentos dos nove municípios que integram essa unidade regional.

5. Conforme a Agem-BS (2019), diante das exigências do Estatuto da Metrópole, o PMDE-BS, elaborado antes da aprovação da lei, conferiu à RM da Baixada Santista grande vantagem, com relação a outras unidades regionais. Assim, "em dezembro de 2015, o CONDESB incumbiu a Câmara Temática de Planejamento da agência de formular o Plano de Trabalho que definiu os conteúdos mínimos, as orientações metodológicas e o cronograma que orientam os debates para a elaboração do projeto de lei complementar do PDUI, incluindo a participação da sociedade civil". Dessa forma, "técnicos da AGEM-BS e das prefeituras da região começaram a discutir a revisão e adequação do PMDE-BS às exigências da lei federal", integrando-o à minuta do PLC do PDUI-BS. Para maior detalhamento dessa questão, ver Carriço e Saleme (2018). 
trabalhos da Câmara Temática de Planejamento e Desenvolvimento Econômico, para "sistematizar as contribuiçôes recolhidas nos dois ciclos de oficinas", foram realizadas audiências públicas nos nove municípios da RM da Baixada Santista, em agosto de 2017. Segundo essa fonte, houve participação considerável de munícipes durante as audiências. Porém, o número de participantes não foi o necessário para garantir ampla participação democrática no processo. Também foram enviadas propostas dos munícipes por via eletrônica, em hotsite especialmente montado pela Agem-BS, para que se pudesse contemplar manifestaçóes dos mais diversos tipos de entidades e opinióes de populares da regiáo. Esse hotsite foi retirado do portal da agência. Portanto, atualmente não se tem mais acesso as informaçóes geradas no período de elaboração do PDUI-BS.

Em 30 de setembro de 2017, em oficina regional, "foram eleitos os quinze representantes da Sociedade Civil" e "escolhidos três representantes entre entidades credenciadas segundo as cinco Funçóes Públicas de Interesse Comum”. (Agem-BS, 2019). Cabe destacar que a Universidade Católica de Santos elegeu um representante no eixo de Habitação e Desenvolvimento Urbano, que passou a integrar a Câmara Temática de Planejamento e Desenvolvimento Econômico, nas questóes relativas ao PDUI-BS.

A partir de então, esses representantes participaram da elaboração do Projeto de Lei (PL) do PDUI-BS, com representantes das prefeituras e do governo do estado que compóem a Câmara Temática de Planejamento e Desenvolvimento Econômico (Agem-BS, 2019). Essa etapa foi encerrada em 14 de novembro de 2017, sendo a minuta de PLC do PDUI-BS encaminhada para homologação do Condesb, o que ocorreu na reuniáo realizada em 28 de novembro de 2017 (op. cit.). Ao longo de 2018, essa comissáo de acompanhamento do PDUI-BS continuou reunindo-se mensalmente, na sede da Agem-BS, para debate e elaboração das frentes definidas no plano de trabalho, conforme já relatado.

A figura 1, a seguir, apresenta o cronograma geral de todo o processo de elaboraçáo do PDUI-BS, da RM da Baixada Santista, de acordo com o pactuado entre a Agem-BS e os integrantes da Câmara Temática de Planejamento e Desenvolvimento Econômico.

FIGURA 1

Cronograma de elaboração do PDUI da RM da Baixada Santista

\begin{tabular}{|c|c|c|c|c|c|c|c|c|c|c|}
\hline $\begin{array}{l}\text { Maio } \\
2014\end{array}$ & $\begin{array}{l}\text { Janeiro } \\
2015\end{array}$ & $\begin{array}{c}\text { AbrillMaio } \\
2015\end{array}$ & $\begin{array}{c}\text { Janeiro } \\
2016\end{array}$ & $\begin{array}{l}\text { Abril } \\
2016\end{array}$ & $\begin{array}{l}\text { Julho } \\
2016\end{array}$ & $\begin{array}{l}\text { Out/Nov } \\
2016\end{array}$ & $\begin{array}{c}\text { Abrilumaio } \\
2017\end{array}$ & $\begin{array}{c}\text { Junho/Agosto } \\
2017\end{array}$ & $\begin{array}{c}\text { Setembro } \\
2017\end{array}$ & $\begin{array}{c}\text { Novembro } \\
2017\end{array}$ \\
\hline $\begin{array}{c}\text { Entrega } \\
\text { do Plano } \\
\text { Metropolitano } \\
\text { de Desenv. } \\
\text { Estratégico }\end{array}$ & $\begin{array}{l}\text { Sançāo da } \\
\text { Lei Federal } \\
n^{\circ} 13.089 \\
\text { EEtatuto da } \\
\text { Metrópole }\end{array}$ & $\begin{array}{l}\text { Início das } \\
\text { discussōes } \\
\text { de adequaçáo } \\
\text { do PMDE a } \\
\text { lei federal }\end{array}$ & $\begin{array}{l}\text { CT de } \\
\text { Planejamento } \\
\text { é definida pelo } \\
\text { Condesb para } \\
\text { centralizar as } \\
\text { discussoes }\end{array}$ & $\begin{array}{l}\text { Condesb } \\
\text { aprova Plano } \\
\text { de Trabalho } \\
\text { da CT de } \\
\text { Planejamento }\end{array}$ & $\begin{array}{c}\text { Realizaçāo } \\
\text { de Oficinas } \\
\text { Temáticas com } \\
\text { especialistas } \\
\text { sobre assuntos } \\
\text { metropolitanos }\end{array}$ & $\begin{array}{c}\text { Reuniōes } \\
\text { da CT de } \\
\text { Planejamento, } \\
\text { preparatórias } \\
\text { para Oficinas } \\
\text { e Audiências } \\
\text { Públicas }\end{array}$ & $\begin{array}{c}\text { Realizaçāo } \\
\text { de Oficinas } \\
\text { Temáticas com } \\
\text { a sociedade } \\
\text { civil organizada }\end{array}$ & $\begin{array}{c}\text { Audiências } \\
\text { Públicas } \\
\text { Municipais }\end{array}$ & $\begin{array}{l}\text { Oficina } \\
\text { Pública } \\
\text { Regional }\end{array}$ & $\begin{array}{c}\text { Conclusāo } \\
\text { da minuta } \\
\text { de projeto } \\
\text { de Lei }\end{array}$ \\
\hline
\end{tabular}

Fonte: Agem-BS (2019). Disponivel em: <https://is.gd/8CqK62>. Acesso em: 29 out. 2019.

Obs.: Figura reproduzida em baixa resolução e cujos leiaute e textos não puderam ser padronizados e revisados em virtude das condições técnicas dos originais (nota do Editorial).

Com relação ao estágio atual do processo de elaboração do PDUI-BS, de acordo com a Agem-BS (2019), a "Secretaria de Desenvolvimento Regional está compatibilizando os PDUIs do Estado". O órgão sugeriu que essa informação seja complementada diretamente pela secretaria, quanto a prazos e entraves.

Dessa forma, via o Sistema Integrado de Informaçóes ao Cidadão do Estado de São Paulo (SIC.SP), em 9 de dezembro de 2019, questionou-se o motivo pelo qual o PLC do PDUI-BS, aprovado em novembro de 2017, pelo Condesb, até entâo náo havia encaminhado à Alesp. Como resposta, em 10 de dezembro de 2019, a Subsecretaria de 
Assuntos Metropolitanos da Secretaria de Desenvolvimento Regional de São Paulo assim se manifestou:

Solicitamos informar ao cidadão interessado que o PDUI é um plano complexo que terá força de lei. Assim, a Assessoria Técnica Legislativa do Governo está fazendo uma análise rigorosa do mesmo, tendo em vista as implicaçôes legais de grande amplitude nas políticas públicas do governo estadual e dos municípios que integram a Região Metropolitana da Baixada Santista (São Paulo, 2019).

Porém, teve-se conhecimento de que a Assessoria Técnica Legislativa do Governo do Estado de Sáo Paulo não aceitou a minuta de PLC, nos termos em que foi encaminhada pelo Condesb. Sabe-se que um dos aspectos questionados acerca da minuta, no tocante à decisão de incorporação do PMDE-BS ao PDUI-BS, respeita à necessidade de atualização das metas definidas no plano metropolitano. De acordo com essa fonte, não há previsão para aprovação da LC do PDUI da RM da Baixada Santista. Tal questionamento também foi feito por representantes da sociedade civil no processo de elaboração do plano de desenvolvimento, em funçáo da nova conjuntura do país e da RM da Baixada Santista. Entretanto, após vários debates na Câmara Técnica de Planejamento e Desenvolvimento Econômico, chegou-se à conclusão que essa questão de atualização das metas do PMDE-BS deveria dar-se por meio da implantaçáo do Sima-BS, coordenada pela Agem-BS.

Um aspecto importante é que a proposta de PLC, se aprovada, transformaria o decreto de regulamentação do macrozoneamento do ZEE-BS em lei estadual, em momento em que a Secretaria de Meio Ambiente está pensando em flexibilizar as regras ambientais. Outra expectativa que havia no governo paulista, à época, era utilizar as zonas de interesse metropolitanos (ZIMs) ${ }^{6}$ como "território especial", onde qualquer atividade fosse possível, nos termos da recém-aprovada Lei Federal da Liberdade Econômica (Lei no 13.874, de 20 de setembro de 2019).

Se considerado o processo de discussão atual do ZEE-BS, no estado de São Paulo, é plausível essa explicação para um dos maiores entraves sofridos pelo PDUI da RM da Baixada Santista, pois o atual governo estadual náo pretende realizar zoneamento com delimitação espacial. $\mathrm{Na}$ época, a direção da Emplasa defendia que o macrozoneamento dos PDUIs deveria mapear apenas as ZIMs, como havia sido feito na primeira versão do plano da RM de Belo Horizonte.

Apesar da demora da Casa Civil do governo do estado em encaminhar à Alesp o projeto de lei complementar do PDUI-BS, aprovado pelo Condesb em novembro de 2017, em recente matéria publicada na imprensa (Plano..., 2020), o atual presidente desse conselho e prefeito de Peruíbe, Luiz Maurício, declarou que o plano "foi elaborado em uma perspectiva diferente da região, principalmente quanto à expectativa que se tinha do pré-sal”. Nessa matéria, o prefeito de Praia Grande, Alberto Mourão, declarou que vai entrar em contato com o "secretário estadual de Desenvolvimento Urbano $(s i c)^{7}$ e, como prefeito, pedir para segurar [o envio à Assembleia] por 30, 60 dias". Na referida reportagem, o prefeito Mouráo justifica sua intenção de "segurar" o PLC, pois o PMDE-BS "precisa de ajustes". Porém, no mencionado projeto do PDUI-BS, não há reprodução de metas e ações previstas no PMDE-BS. O inciso I do art. $3^{\circ}$ da propositura apenas dispóe que o PDUI-BS é composto pelo:

Plano Metropolitano de Desenvolvimento Estratégico da Baixada Santista - PMDE-BS, aprovado por deliberação do Condesb n⿳o 019, de 29 de junho de 2017, complementado pelo Plano Metropolitano de Desenvolvimento Integrado - PMDI-BS em seus casos omissos (Minuta de PLC do PDUI aprovada pelo Condesb).

6. As ZIMs consistiam em uma proposta de institucionalização de um instrumento urbanístico especial, estudada no âmbito da Emplasa. 7. Na verdade, a pasta responsável denomina-se desenvolvimento regional. 
Portanto, há claramente um movimento no sentido de postergar ainda mais o envio do plano à Alesp, pois a revisão do PMDE-BS poderia ocorrer durante a tramitaçáo do PLC na assembleia ou até mesmo poderia ser inserido no artigo um parágrafo estabelecendo prazo para a atualização do plano metropolitano.

Esse art. 3o, que também elenca como componentes do PDUI-BS o ZEE-BS e o Sima-BS, é resultado da proposta do corpo técnico da Agem-BS, que procurou consolidar, com os municípios, alguns regramentos já existentes, adotando o decreto do ZEE-BS, da mesma forma em que, na RM de São Paulo, se fez a consolidaçáo das leis específicas dos planos de bacia das áreas de proteção aos mananciais. Nos meios técnicos dos municípios, a maioria concordou com a proposta, pois se sentiu mais segura com essa consolidação em uma lei estadual, contribuindo para que a minuta fosse aprovada pelo Condesb.

O PDUI da RM da Baixada Santista foi o primeiro a ser realizado no estado de São Paulo, em uma época em que havia grande resistência, por parte do governo estadual, em aceitar a participação da sociedade civil no âmbito da instância deliberativa. Isso pode ser observado na primeira cartilha do processo de elaboraçáo do PDUI da RM de Sáo Paulo, que colocava a participaçáo da sociedade civil apenas no final. Somente após pressão do Ministério Público do Estado de São Paulo (MP-SP), o governo aceitou criar um colegiado com participação da sociedade civil desde o início dos trabalhos.

Embora o Estatuto da Metrópole seja claro, exigindo a participação da sociedade civil em uma instância deliberativa - ou seja, no Condesb -, o governo entendeu que, para isso, seria necessário emendar a Constituição do estado de São Paulo. Por essa razão, para a criação do PDUI da RM da Baixada Santista, terminou-se por adotar a soluçáo de criar uma comissão de acompanhamento da elaboração da proposta de PDUI-BS, com participaçáo da sociedade civil.

Essa situação de indefinição da aprovação do PDUI-BS ganhou novos contornos com a revogação do art. 21 do Estatuto da Metrópole, eliminando-se prazo e sanção para os agentes públicos que não adotarem as providências para sua aprovação. Outro aspecto que também merece destaque é a forma atual de negociação de verbas e investimentos estaduais, entre governo e municípios, sem passar por discussão metropolitana, facilitando a elaboração de convênios bilaterais de acordo com conveniências político-partidárias, prejudicando a discussão e a resolução dos problemas atinentes às FPICs, de forma conjunta e transparente.

Quanto à aderência do PDUI-BS e sua implementação, é importante ressaltar que o Sima-BS já foi implantado, e, no tocante às suas metas, "estão sendo trabalhadas junto aos municípios", em fase de treinamento inicial (Agem-BS, 2019), o que se "caracteriza como um importante diferencial e avanço para o planejamento e gestão metropolitanos", de acordo com a Agem-BS. Contudo, até o momento, a sociedade civil e os técnicos dos próprios municípios não têm acesso ao sistema.

Deve-se destacar que a primeira edição do Fórum Social da Baixada Santista (FSBS), organizada em 2017, por vários movimentos sociais da regiáo, pautou a discussáo do PDUI-BS em evento realizado em 15 de dezembro desse ano. Como consequência, em 23 de março de 2019, essas entidades, lideradas pelo Fórum da Cidadania de Santos, realizaram um seminário para tirar encaminhamentos, no sentido de promover discussão mais ampla acerca da importância do plano e de sua aprovaçáo. Isso ocasionou a proposta de criaçáo do programa denominado Baixada Viva para construçáo de uma agenda metropolitana, com a efetiva participação da sociedade civil. 
Como consequência, no início do segundo semestre de 2019, algumas das entidades que participaram desse processo procuraram instituições de ensino e pesquisa locais, solicitando apoio para elaboração de diagnóstico regional, a partir do entendimento de que a crise econômica tem atingido a RM da Baixada Santista de forma mais intensa do que em outras regióes do estado. Esse movimento acabou envolvendo políticos da região, bem como representaçôes do setor púbico e privado, tendo como consequência a criação do movimento denominado Inova - Região Metropolitana da Baixada Santista, com vistas ao desenvolvimento econômico e social da região. Esse movimento foi lançado oficialmente em 21 de agosto de 2019, e sua coordenação é colegiada, composta por instituições de ensino e pesquisa, com a participação da UniSantos, na coordenação geral. ${ }^{8} \mathrm{O}$ diagnóstico regional foi articulado em seis eixos, estando a questão da governança metropolitana presente de forma transversal.

Em 8 e 9 de novembro de 2019, foi realizada a segunda edição do FSBS, na qual a questão metropolitana integrou novamente a pauta de discussão, no dia de abertura do fórum, no âmbito da mesa RM da Baixada Santista em Questão. Ademais, realizaram-se atividades autogeridas, propostas por representantes da sociedade civil organizada; entre estas, a UniSantos.

Portanto, observa-se que setores da sociedade estão se organizando de várias formas, com o objetivo de discutir a questão da governança regional. Porém, o papel estatal nesse processo tem revelado a não priorização do planejamento metropolitano, pois limitou-se à implantaçáo do Sima-BS, a qual sofreu grande atraso com o impasse provocado pelo governo do estado, que, no início de 2019, desmontou as agências metropolitanas, provocando um hiato de meses na atuação técnica dessas autarquias. Esse hiato prejudicou o cronograma previsto de implantação do PDUI-BS, agravado pela liquidação da Emplasa e pelo não encaminhamento do PLC do PDUI à Alesp. Ao mesmo tempo, não se observa, por parte dos municípios, preocupação em cobrar do estado o aperfeiçoamento da estrutura de governança, nem a celeridade necessária para aprovação do PDUI-BS.

\section{COMPATIBILIZAÇÃO COM OS PLANOS DIRETORES}

Como o PDUI-BS incorporou o macrozoneamento do ZEE-BS, e este já havia levado em consideração os planos diretores municipais, não houve conflitos com os municípios da região, durante o processo de elaboração da minuta de PLC. Na verdade, os maiores conflitos ocorreram durante a discussão do macrozoneamento do ZEE-BS, o que levou à publicaçáo do decreto regulamentador, do setor costeiro da RM da Baixada Santista, apenas em 2013; quinze anos após a aprovaçáo do Plano Estadual de Gerenciamento Costeiro (PEGC), instituído pela Lei nº 10.019/1998, ${ }^{9}$ a qual, por sua vez, apenas ocorreu dez anos após a aprovaçấo da Lei federal no 7.661/1988, que instituiu o Plano Nacional de Gerenciamento Costeiro (PNGC).

Quanto à compatibilização do Plano Diretor de Desenvolvimento e Expansão Urbana do Município de Santos, polo regional, com o PDUI-BS, deve-se ressaltar que, na ocasiáo da elaboraçáo do PLC, vigorava a LC no 821, de 27 de dezembro de 2013, que estabeleceu o plano diretor. Segundo o art. $4^{\circ}$ dessa norma, eram objetivos desse plano:

8. Para maiores informações acerca do Inova-BS, ver matéria de $A$ Tribuna (Projeto..., 2019).

9. O PEGC de São Paulo estabeleceu objetivos, diretrizes, metas e instrumentos para sua execução, com a finalidade de disciplinar e racionalizar a utilização dos recursos naturais da zona costeira. A lei estadual definiu a tipologia das zonas costeiras, seus usos permitidos, as atividades proibidas e as penalidades a serem aplicadas no caso de infrações. Por fim, a lei estabeleceu que o licenciamento e a fiscalização deveriam ser realizados com base em normas e critérios estabelecidos no ZEE, a ser instituído mediante decreto estadual, sem prejuízo das demais normas estaduais, federais e municipais definidas pelos órgãos competentes. 
I. Assegurar o desenvolvimento econômico sustentável do Município, observando os planos nacionais, regionais, estaduais e metropolitanos, e a universalização do uso dos espaços urbanos, visando à acessibilidade, à mobilidade e à comunicação para toda a comunidade, à melhoria da qualidade de vida e ao bem-estar da coletividade, especialmente nas áreas com baixos índices de desenvolvimento econômico e social;

II. Fortalecer a posição do Município como polo da Região Metropolitana da Baixada Santista - RMBS e na rede urbana nacional;

III. adequar e promover a compatibilização do processo de planejamento ambiental e normatização do território do Município aos planos e projetos regionais, estaduais e nacionais;

IV. Promover a cooperaçẫo e a articulação com a Agência Metropolitana da Baixada Santista - AGEM e os demais municípios da Região Metropolitana da Baixada Santista, fortalecendo a gestão integrada;

V. Instituir e diversificar as formas de parcerias entre o Poder Público Federal, Estadual, Municipal, iniciativa privada e entidades civis na elaboração e execução dos projetos de interesse público que dinamizem o setor produtivo;

VI. Promover a integração entre os sistemas municipais de circulação e transporte local e regional;

VII. Estabelecer as normas gerais de proteção, recuperação e uso do solo no território do Município, visando à redução dos impactos negativos ambientais e sociais;

VIII. Instituir os incentivos fiscais e urbanísticos que estimulem o ordenamento do uso e ocupação do solo, promovendo de forma integrada o equilíbrio econômico, social e ambiental;

IX. Orientar as dinâmicas de produção imobiliária, com adensamento e diversificação de usos ao longo dos eixos de transporte coletivo público e nas áreas de centralidades com concentração de atividades não residenciais;

X. Fortalecer os mecanismos de compensação ambiental para as atividades que importem em desmatamento ou alteração dos ecossistemas originais;

XI. Priorizar a participaçáo e a inclusão social de toda a população nos processos de desenvolvimento da cidade, em todos os setores (Santos, 2013, art. 4º , grifo nosso).

Portanto, conforme se observa, os objetivos do Plano Diretor de Desenvolvimento e Expansão Urbana do Município de Santos, de 2013, estavam em sintonia com o PDUI, antes mesmo de sua elaboração. Contudo, as principais leis regulamentadoras deste plano eram as leis de ordenamento do uso e da ocupação do solo nas áreas continental e insular, ${ }^{10}$ respectivamente, LCs no 729, de 11 de julho de 2011 (Santos, 2011a), e no 730, de 11 de julho de 2011 (Santos, 2011b). Em ambos os casos, os zoneamentos aprovados estavam compatibilizados com o ZEE-BS.

Em 2018, houve revisão do Plano Diretor de Desenvolvimento e Expansão Urbana do Município de Santos e da Lei de Ordenamento do Uso e da Ocupação do Solo na Área Insular do município. Esse processo resultou na aprovação das LCs no 1.005 , de 16 de julho de 2018, e no 1.006 , de 16 de julho de 2018; respectivamente, o novo plano diretor (Santos, 2018a) e a nova Lei de Ordenamento do Uso e da Ocupaçáo do Solo na Área Insular (Santos, 2018b). O processo de revisão da Lei de Ordenamento do Uso e da Ocupação do Solo na Continental ainda se encontra em estágio inicial.

10. 0 município de Santos é dividido em duas macrozonas, continental e insular, sendo que a cidade de Santos se localiza na Insular, mais especificamente na llha de São Vicente, onde vivem 99\% da população do município, de acordo com o Censo Demográfico 2010 , do Instituto Brasileiro de Geografia e Estatística (IBGE). 
De acordo com o art. 4ำ do Plano Diretor de Desenvolvimento e Expansão Urbana do Município de Santos, os objetivos elencados nesse artigo foram pouco alterados, sendo as redaçóes dos incisos I, II, III, IV e VI idênticas às da LC no 821/2013 (Santos, 2013). No caso da LC no 1.006/2018 (Santos, 2018b), o zoneamento da macrozona insular sofreu várias alteraçóes; porém, em nenhum caso, houve conflito com o estabelecido no macrozoneamento do ZEE-BS, determinado pelo Decreto Estadual no 58.996/2013. Portanto, pode-se afirmar que o ordenamento urbanístico do polo regional náo conflita com o disposto na proposta de PDUI-BS.

\section{MAPEAMENTO DE CONFLITOS DE USO DO SOLO: IDENTIFICAÇÃO, TIPOLOGIAS E DESAFIOS/SOLUÇÕES}

Situada na zona costeira do estado de São Paulo, a RM da Baixada Santista ocupa área de domínio do bioma Mata Atlântica. Náo obstante tratar-se de meio físico rico em biodiversidade e altamente vulnerável às intervençóes antrópicas, as condições excepcionais de seu estuário (as conexóes ligando baixada e planalto e a presença de praias) favoreceram o desenvolvimento do complexo portuário de Santos, do polo petroquímico siderúrgico de Cubatão e de atividades turísticas em oito dos seus nove municípios que oferecem orla oceânica.

O processo de ocupação urbana gerado por essas atividades impôs grande pressão sobre a capacidade de suporte dos ambientes costeiros, na medida em que ocorreu sobre enseadas, praias, dunas, estuários e até mesmo costóes rochosos. Este suprimiu áreas de restinga e manguezais, cujos remanescentes sofrem os efeitos da degradação ambiental e da contaminação por efluentes domésticos e industriais, ocasionando também a conurbação entre os municípios centrais da RM da Baixada Santista, apesar das barreiras geográficas entre continente e ilhas (São Vicente e Santo Amaro).

A RM da Baixada Santista convive com conflitos ambientais derivados das citadas atividades, os quais, em muitos momentos, desencadearam eventos extremos, como a crise deflagrada com a poluição do ar de Cubatáo, cujo ápice ocorreu com o decreto estadual que declarava Cubatão área crítica de poluição ambiental (1982). Essa medida acarretou, no decorrer daquela década, restriçóes severas à implantação de novas plantas industriais, assim como a ampliação das existentes. Ainda em Cubatão, em 1984, os efeitos da poluição sobre as encostas da Serra do Mar desencadearam, em período de chuvas de pouco mais de 48 horas, múltiplos escorregamentos, sinalizando degradação da vegetação e riscos aos moradores e às instalaçóes industriais, eventos que mobilizaram a população regional na cobrança de medidas de contençáo dos agentes causadores do problema. Esse acontecimento resultou na implantação, pela Companhia Ambiental do Estado de Sáo Paulo (Cetesb), em 1983, do Programa de Controle e Recuperação da Qualidade Ambiental de Cubatão, que teve importante papel no controle e na fiscalização das indústrias.

Nos anos 1990, a poluição das praias de Santos e São Vicente, por coliformes fecais oriundos das áreas não servidas por coleta e/ou tratamento de esgotos, atingiu níveis alarmantes, ensejando pressóes para interdição das praias para banhos de mar. Como resultado, houve ampliação do programa de avaliação periódica da balneabilidade das praias do litoral paulista pela Cetesb e a intensificaçáo do Programa Caça-Esgotos, desenvolvido em parceria com a Prefeitura de Santos.

As atividades portuárias sempre estiveram no rol de conflitos de uso, principalmente em função da necessidade de compartilhar espaços com outras atividades urbanas $;{ }^{11}$ porém,

11. Para um aprofundamento acerca dos conflitos entre atividades portuárias e retroportuárias e a cidade de Santos, ver Barros e Carriço (2019), que abordam as relações entre o esvaziamento da área central de Santos, ao longo do século XX, e essas atividades. 
as incompatibilidades intensificaram-se com o advento do contêiner na década de 1970 . A nova modalidade de transporte alterou significativamente a estrutura do porto: introduziu novas tecnologias na movimentação de cargas e demandou espaços de operações com dimensões que as antigas instalações não ofereciam, obrigando a expansão para a margem esquerda do estuário, no município de Guarujá, onde foi instalado o terminal de contêineres (Tecon). O processo de construção e as operações do terminal afetaram diretamente as comunidades pesqueiras de Conceiçãozinha e Prainha, tanto pela interferência na atividade de pesca quanto pela disputa das áreas por estas ocupadas, situação que perdura até hoje.

Nas primeiras décadas do século XXI, novas exigências logísticas impeliram o avanço de terminais portuários para a área continental de Santos, movimento amparado por alteraçôes da legislação urbanística, que com isso sinalizou que, para a política de desenvolvimento do município, o continente é o novo vetor de crescimento do complexo portuário.

A porção continental de Santos representa mais de $90 \%$ da área do território do município, embora abrigue menos de $1 \%$ de sua populaçáo, compondo um dos complexos costeiros mais ricos do mundo, ainda bastante preservado. Os usos predominantes eram os relacionados com mineraçáo (pedreiras), atividades agrícolas pouco expressivas e núcleos urbanos rarefeitos e de baixa densidade, representados não somente por assentamentos residenciais (Caruara, Monte Cabrão e Ilha Diana), como também por sítios arqueológicos e históricos. Todavia, essa riqueza ambiental e o único agrupamento caiçara remanescente no município (o núcleo denominado Ilha Diana) sofreram grandes impactos após a expansão portuária para a área continental, com a instalação de grande terminal portuário em 2003.

A área é formada basicamente por floresta ombrófila densa, escarpas da Serra do Mar e manguezais, apresentando dois vales encaixados entre montanhas, Quilombo e Jurubatuba, ambos possuidores de mananciais de abastecimento de água. Apresenta ainda alguns anfiteatros, drenados por cursos d'água nascidos na Serra do Mar e que desaguam no estuário de Santos e no canal de Bertioga.

Parte dos manguezais encontra-se alterada por assoreamento e contaminação química causada pelos efluentes das atividades portuárias e industriais, mas, mesmo assim, presta relevante serviço ambiental. Para Menghini (2004), embora altamente degradados, os manguezais da Baixada Santista continuam funcionando como barreira aos sedimentos, sendo que sua supressão implicará dragagens mais constantes, acarretando altos custos à manutenção do canal de navegação e riscos de contaminação pelos resíduos dragados.

Por sua importância à manutenção dos ecossistemas terrestres e à preservação do ambiente marinho, recaem sobre a área continental de Santos quatro unidades de conservação: i) Parque Estadual da Serra do Mar (PESM); ii) Área de Proteção Ambiental Marinha (APAMLC); iii) Parque Estadual Marinho da Lage de Santos (PEMLS); e iv) Área de Proteção Ambiental Santos Continente (Apasc). Incidem também o Código Florestal e as resoluções do Conselho de Defesa do Patrimônio Histórico, Arqueológico, Artístico e Turístico do Estado de São Paulo (CONDEPHAAT), que definem a área de tombamento do PESM e adjacências (mapa 1). Na figura 2, no detalhe, em linha cheia, observa-se o limite do polígono de tombamento da Serra do Mar. Nessa figura, a montante, em linha pontilhada, o limite do polígono do Parque Estadual da Serra do Mar.

A Área de Proteção Ambiental (APA) Santos Continente, unidade de conservação de âmbito municipal, sancionada pela LC no 54/1992, ao definir o zoneamento ambiental, determinou cinco zonas, cujo manejo vai de maior à menor restrição, incluindo-se áreas para 
fins urbanos e três zonas especiais: $i$ ) de suporte urbano; ii) de preservação histórico-cultural; e iii) de recuperação. Além disso, estabeleceu índices urbanísticos, objetivando orientar a implantação de empreendimentos em que estes fossem permitidos, mas de acordo com a capacidade de suporte dos ecossistemas. A área de manguezal foi delimitada como zona de recuperaçáo (ZR), com o objetivo de recompor suas características originais, resgatando a integridade biofísica e garantindo suas funções naturais.

MAPA 1

Áreas protegidas e áreas não passíveis de ocupação na RM da Baixada Santista

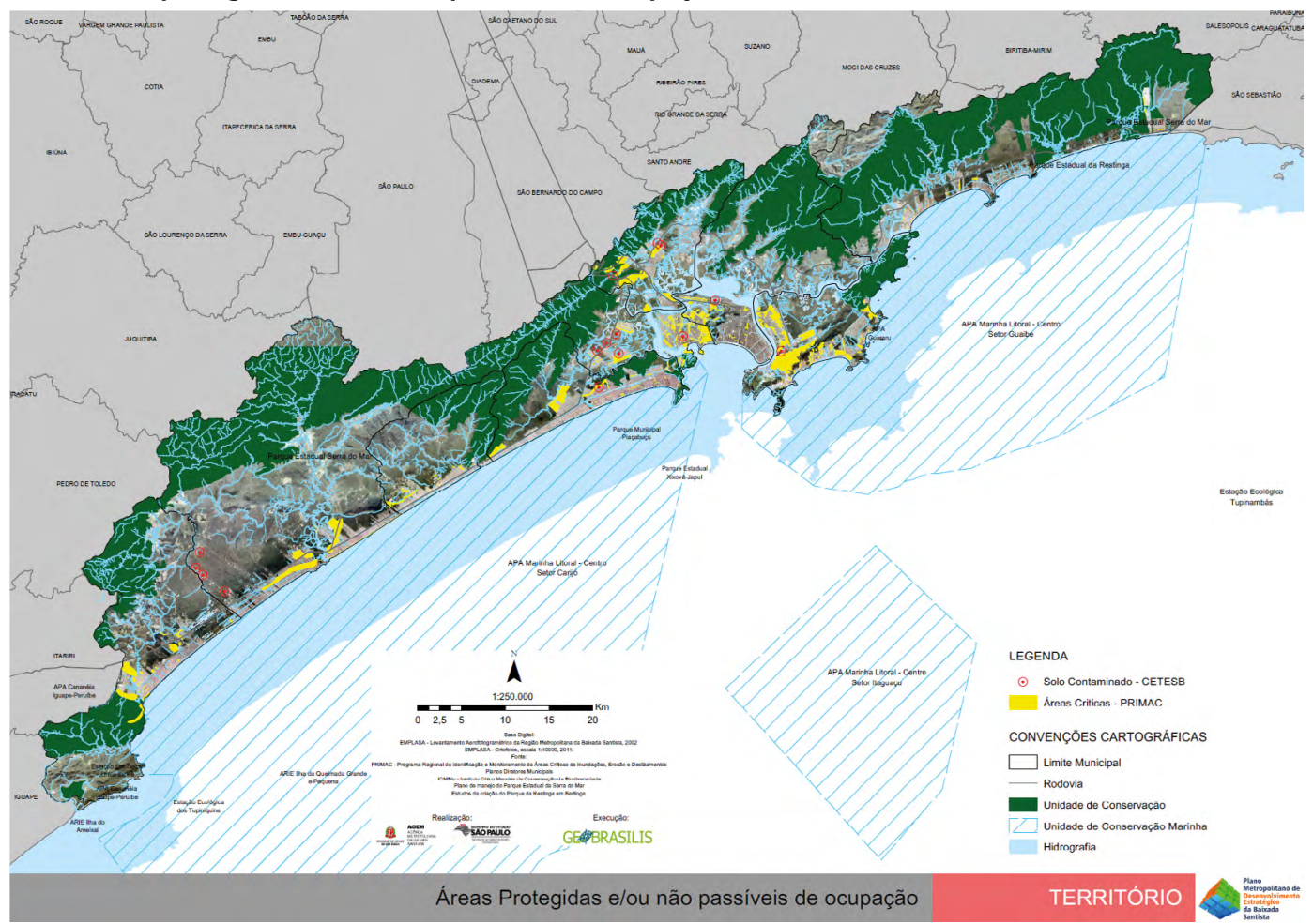

Fonte: PMDE-BS (Agem-BS, 2014).

FIGURA 2

Trecho do polígono de tombamento da Serra do Mar

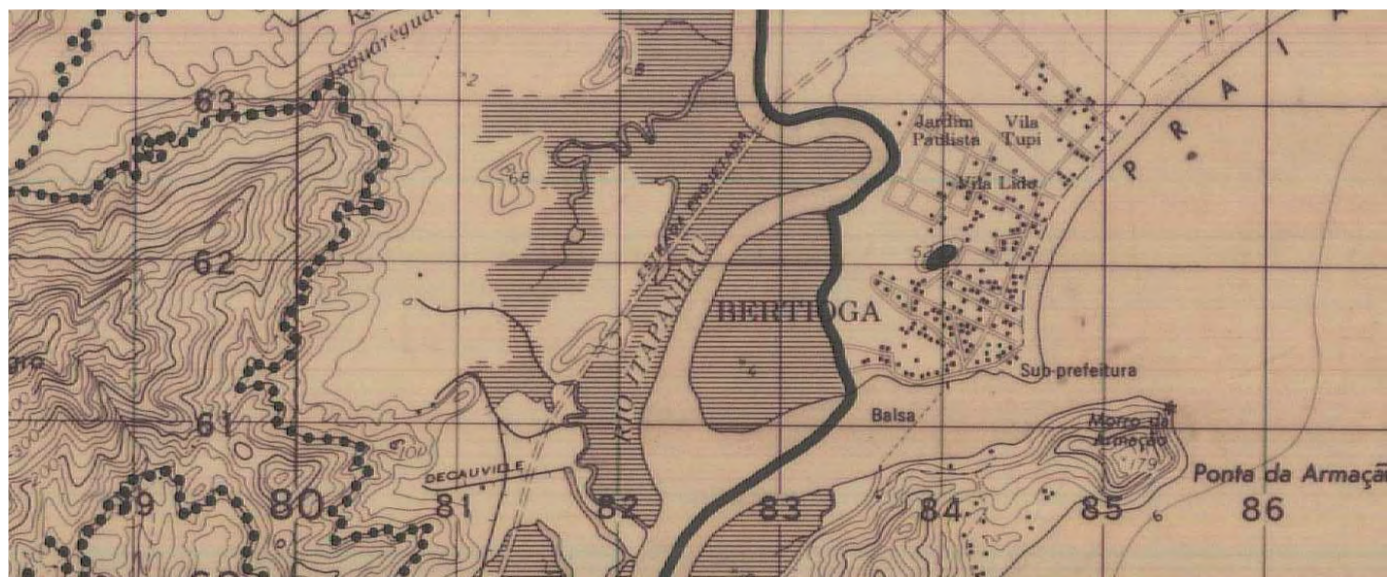

Fonte: Furlan (2018, p. 75) 
Em 1998, com um novo plano diretor, $\mathrm{LC}^{\mathrm{o}}{ }^{3}$ 31, de 23 de novembro (Santos, 1998), regulamentado pela LC no 359, de 25 de novembro de 1999 (Santos, 1999), que instituiu o novo ordenamento do uso e da ocupação do solo na área continental do município, a compartimentação do território continental foi alterada e a APA dividida em duas áreas com características distintas: $i$ ) área de expansão urbana; e ii) área de proteção ambiental. $\mathrm{Na}$ primeira, estava contida a área de manguezal, cujo uso foi liberado para instalaçôes portuárias e retroportuárias, sob a justificativa de tratar-se de área degradada, desconsiderando-se a possibilidade e a importância da recuperação desse sistema para o equilíbrio do estuário, que, contraditoriamente, foi incorporado no macrozoneamento do ZEE-BS, aprovado por decreto em 2013.

Ao reordenar o território continental de Santos, objetivando viabilizar espaço para novas atividades do complexo portuário e indicando a área de manguezal como estratégica para abrigar atividades portuárias, retroportuárias, logísticas e de desenvolvimento tecnológico, a política de desenvolvimento traçada pela $\mathrm{LC} \mathrm{n}^{-}$359/1999 comprometeu importante componente de equilíbrio do ambiente terrestre e marinho, bem como tornou vulneráveis as áreas de preservação remanescentes.

A lei de ordenamento do uso e da ocupaçáo do solo na área continental em vigor (LC no 729/2011) reafirmou as diretrizes de 1999, delimitando, na área integrada de expansão urbana, a Zona Portuária e Retroportuária (ZPR), definindo-a como passível de receber instalaçôes rodoviárias, ferroviárias, portuárias e retroportuárias, assim como atividades náuticas. Delimita também as zonas de suporte urbano (ZSU) I e II, passíveis de atividades retroportuárias e apoio logístico e a zona urbana $(\mathrm{ZU})$, destinada à implantação de parque tecnológico. ${ }^{12}$ Importante destacar que a citada lei explicita, em seus objetivos, que a redefiniçáo do uso do manguezal observou fatores relacionados ao potencial que a área oferece, em alusão ao fato de seu território ser servido pela rodovia Cônego Domenico Rangoni, parte do importante complexo que liga a rodovia Rio Santos e o Sistema Anchieta Imigrantes com o planalto.

A mudança legal, efetuada em 1998, gerou resultados imediatos. Em 2003, teve início a construção do Terminal da Empresa Brasileira de Terminais Portuários (Embraport), adquirida pela multinacional DP World Santos, em 2018, com previsão de obras de expansão até 2020. O empreendimento conta com $653 \mathrm{~m}$ de cais, 207 mil metros quadrados de pátio e capacidade de movimentação anual de 1,2 milhão de contêineres, 200 mil veículos, 2 milhões de toneladas de graneis sólidos vegetais e cerca de 5 milhóes de granéis líquidos (Santos, 2015).

Localizado na foz dos rios Diana e Sandi, o terminal encontra-se bem próximo à Ilha Diana, assentamento de comunidade tradicional, que tem a pesca e a agricultura familiar como base da economia. O conflito de usos é evidente, embora - do ponto de vista legal - o terminal da Embraport situe-se na área de expansão urbana e a Ilha Diana, que com este faz vizinhança, na área de proteçáo ambiental e, portanto, amparada, em tese, por objetivos de proteção de seus recursos ambientais e da população residente (figura 3). No entanto, os conflitos acumulam-se desde a etapa de obras, posto que o aterramento do manguezal, além de risco de alagamentos na área do assentamento, tem produzido impacto negativo na produtividade pesqueira das áreas tradicionalmente procuradas pelos pescadores (Santos, 2019a).

12. De acordo com Santos (2012), "Parques Tecnológicos são áreas especialmente delimitadas com o objetivo de promover pesquisa, 0 desenvolvimento e a inovação tecnológica, estimular a cooperação entre instituições de pesquisa, universidades e empresas e dar suporte ao desenvolvimento de atividades intensivas em conhecimento", oferecendo "oportunidade para as empresas do Estado transformarem pesquisa em produto". 
FIGURA 3

Alterações do ambiente no entorno da Ilha Diana (1962-2014)

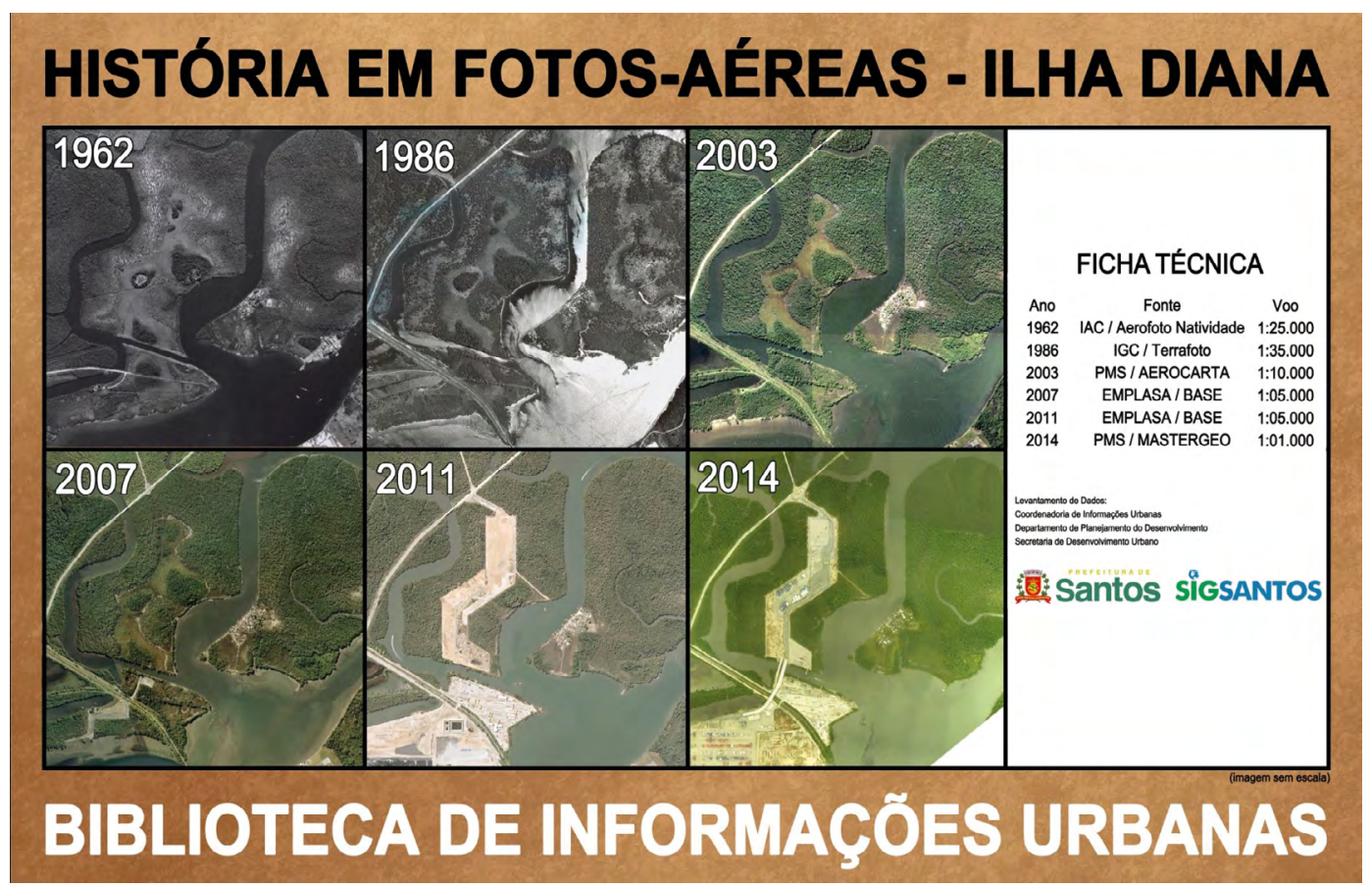

Fonte: Santos, 2016.

Obs.: Figura cujos leiaute e textos não puderam ser padronizados e revisados em virtude das condições técnicas dos originais (nota do Editorial).

Essas interferências recaem sobre um grupo humano altamente vulnerável. Segundo levantamento feito pela Prefeitura Municipal de Santos, em 2010, o núcleo era formado por 55 chefes de famílias, totalizando 181 habitantes; a maioria com grau de escolaridade fundamental incompleto, denotando baixa capacidade de inserção em mercado de trabalho que exige maior grau de escolaridade e qualificação (Viana, Rios e Torres, 2017). Segundo abaixo-assinado feito pela comunidade para emissão do termo de autorização de uso sustentável (Taus) da Ilha Diana, são hoje 61 famílias, total de cerca de duzentos habitantes. Trata-se de populaçáo fragilizada pela perda da qualidade do ambiente marinho, do qual tiravam sustento, devido a perturbaçôes decorrentes principalmente do aterramento do manguezal e a poluição das águas. A pesca - que, ao lado da agricultura, constituía a principal atividade das famílias em décadas passadas - resume-se, segundo relato de moradores, a seis pescadores e quinze mulheres marisqueiras. Grande parte dos moradores declarou trabalhar na prestação de serviços, denotando atividades ligadas ao setor informal (op. cit.).

Pesquisa realizada por Santos (2015) revelou que as açôes de compensação socioambiental, ajustadas para aprovação da instalação e funcionamento do empreendimento portuário, não foram efetivamente cumpridas. $\mathrm{O}$ autor cita, entre os compromissos não realizados, cursos de capacitação para o trabalho de moradores da ilha no terminal, reurbanização do assentamento com instalação de infraestrutura de saneamento básico e energia, assim como desenvolvimento de novas atividades econômicas geradoras de renda. Nesse último quesito, o autor ressalta o ainda incipiente projeto socioambiental de turismo de base comunitária, denominado Vida Caiçara: Educação Ambiental e Turismo Comunitário, que já existia antes da instalaçáo do terminal portuário.

Apesar disso, as expectativas do poder público e do setor empresarial é que o Porto de Santos amplie e modernize suas instalaçóes, tornando-se mais competitivo para enfrentar o aumento mundial da demanda de comodities previsto para os próximos anos, assim como a possível retomada dos investimentos na camada do pré-sal. 
Nesse sentido, o relatório Santos: diretrizes preliminares para a área continental e projetos estratégicos (Santos, 2019b), apresentado pela Prefeitura de Santos para discussão, ressalta a existência de terminais que já estão em operação (DP World Santos) e as potencialidades dos espaços legalmente delimitados e disponíveis na área continental para expansão do complexo portuário de Santos. O documento cita como exemplo o Terminal Santorini que obteve licença prévia em 2016, mas ainda náo foi implantado, e aponta possibilidades consideradas estratégicas, como a aprovação de uma zona de processamento de exportaçôes (ZPE) em Santos, área de livre comércio que oferece tratamento tributário, cambial e administrativo diferenciado para empresas cujas atividades estejam voltadas ao mercado externo. A questão da ZPE foi tratada entre 2007 e 2014 na Alesp e também na Câmara Federal, e estava indicada implantação na RM da Baixada Santista em área a ser definida. Ao retomar o tema, trazendo a proposta para Santos, o relatório ressalta as vantagens competitivas oferecidas pelo município, em face da disponibilidade de áreas legalmente definidas para fins portuários, retroportuários e apoio logístico no setor continental.

O relatório apresenta, ainda, estudo de viabilidade de zona de atividades logísticas (ZAL), que constitui área destinada a operaçôes de transferência de meios de transportes e outras atividades logísticas, assim como comércio e gestão. Chegou-se a desenhar um modelo de implantação no território, com o objetivo de mostrar as vantagens legais e locacionais que a área continental de Santos oferece.

Em síntese, até hoje a região convive com conflitos gerados pelo meio físico rico em biodiversidade, todavia vulnerável à açáo antrópica. $\mathrm{O}$ porto - grande vetor do crescimento regional, que deveria otimizar o uso das áreas portuárias já existentes -está se expandindo para a área continental de Santos, que oferece não apenas vantagens locacionais, mas também grandes limitaçóes, por tratar-se de regiáo de Mata Atlântica, ainda relativamente bem preservada (figura 3). A área destinada à expansão portuária é manguezal degradado, mas ainda passível de recuperação, com importante função ambiental de minimizar a quantidade de sedimentos que se depositam no canal do estuário, reduzindo a frequência de dragagens e economizando custos para manter o canal do porto em condições de navegaçáo. A recente implantação de um terminal nas proximidades de núcleo de população tradicional evidenciou graves conflitos, e, em que pesem o estudo de impacto ambiental-relatório de impacto ambiental (EIA-Rima) e suas recomendaçóes de minimização de impactos e compensaçóes, a população convive com risco de inundaçôes e com piora de suas condiçôes de sobrevivência pela impossibilidade de praticar a pesca artesanal, essencial para a gastronomia e o turismo de base comunitária dessa comunidade.

O caso da área continental de Santos serve como um exemplo das pressões sobre o ambiente natural que, historicamente, ocorrem em toda a RM da Baixada Santista, colocando em conflito a preservação do meio ambiente ecologicamente sustentável e o desenvolvimento econômico. Desde a divisa entre Bertioga e o litoral norte de São Paulo, até a área da Jureia-Itatins, em Peruíbe, são variados os casos de conflitos entre as propostas de implantação de empreendimentos portuários, os interesses de comunidades tradicionais e a preservação ambiental. Apontar formas eficientes e eficazes de gerenciar esses conflitos, planejar a ocupaçáo do território e garantir um desenvolvimento econômico verdadeiramente sustentável é o que se espera do PDUI-BS, o qual precisa ser aprovado, colocado em prática e monitorado pela instância de governança interfederativa, com participação plena da sociedade civil. 


\section{CONSIDERAÇÕES FINAIS}

O processo de elaboraçáo do PLC do PDUI da RM da Baixada Santista teve algumas particularidades, resultantes da estruturaçáo institucional da própria região, durante os anos anteriores à sanção do Estatuto da Metrópole. Menos de dois anos antes da sanção da norma federal, após longo processo de discussáo, o governo do estado havia publicado o decreto que definiu o macrozoneamento do ZEE-BS. E, menos de um ano antes, a Agem-BS havia concluído o PMDE-BS, que - embora fosse um plano com elevado nível de aprofundamento - não dava conta de todas as dimensões inerentes às FPICs, em especial das políticas sociais. Isso levou à Câmara Temática de Planejamento e Desenvolvimento Econômico da Agem-BS a propor, ao Condesb, a incorporação à proposta de PDUI-BS do macrozoneamento do ZEE-BS e do próprio PMDE-BS, com suas diretrizes, metas e açóes, acrescido das dimensóes de análise, que representavam lacunas importantes no plano recém-criado, como foi o caso do eixo social. Essa proposta foi aceita pelo Condesb, que determinou a realização do processo de elaboraçáo do PDUI-BS, por meio de oficinas, audiências públicas e criação de um hotsite no portal da Agem-BS.

Embora o governo de Santos tenha resistido em dotar a RM da Baixada Santista de instância deliberativa com plena participação da sociedade civil, no processo de elaboração da minuta de PLC do PDUI, foram registrados avanços importantes, no nível de participação da sociedade, comparando-se aos processos anteriores. Como resultado, no final de 2017, o Condesb encaminhou a propositura à Casa Civil do governo de Santos, com a promessa de novas perspectivas em termos de governança e planejamento regionais.

A despeito de todo o esforço realizado, a proposta ainda não foi encaminhada pela Casa Civil à Alesp, provocando enorme atraso no aludido processo de governança e planejamento. Embora a Agem-BS não possa informar, tem-se conhecimento de que a Procuradoria Jurídica da Casa Civil colocou óbices ao envio do PLC à assembleia legislativa, com a redação originalmente proposta. A natureza desses óbices é incerta, mas resulta em um impasse que precisa ser superado pela RM da Baixada Santista. E, recentemente, prefeitos da regiáo manifestaram intenção de retardar ainda mais o envio da propositura ao Legislativo estadual.

Esse impasse tem sido agravado pelos retrocessos da gestão da política metropolitana paulista, que reorganizou administrativamente conselhos e agências metropolitanos. Além disso, determinou a liquidação da Emplasa, criada em 1975, com ampla acervo e tradição no planejamento metropolitano do estado de São Paulo, fragilizando todo o apoio técnico prestado aos órgãos regionais.

Contudo, pode-se afirmar que, no processo de elaboração do PDUI-BS, registrou-se a compatibilizaçáo dos planos diretores municipais com o macrozoneamento do ZEE-BS. Mas - como se verificou no estudo de caso apresentado - as contradiçóes entre preservação ambiental, equilíbrio social e desenvolvimento econômico são relevantes, bem como apontam para a urgência da implantação de sólida governança metropolitana, amparada por PDUI-BS amplamente democrático, que represente pacto social legítimo, de forma a garantir o tão almejado desenvolvimento integrado e sustentável da RM da Baixada Santista.

\section{REFERÊNCIAS}

AGEM-BS - AGÊNCIA METROPOLITANA DA BAIXADA SANTISTA. Plano Metropolitano de Desenvolvimento Estratégico da Baixada Santista: caderno de mapas. Santos: Agem-BS; GeoBrasilis, 2014. 
. Documento com resposta aos questionamentos apresentados pela equipe do ponto focal da RMBS: com base no roteiro do relatório [mensagem institucional]. 31 out. 2019.

BARROS, M. F.; CARRIÇO, J. M. Esvaziamento e transformação morfológica da área central de Santos/SP: gênese e perspectivas. Revista Brasileira de Gestáo Urbana, v. 11, p. 1-22, 30 maio 2019.

CARRIÇO, J. M.; SALEME, E, R. Dos planos municipais ao Plano de Desenvolvimento Urbano Integrado: a aprovação do Plano de Desenvolvimento Urbano Integrado pela região metropolitana da Baixada Santista. In: MARGUTI, B.; COSTA, M. A.; FAVARÂO, C. B. (Orgs.). Brasil metropolitano: desafio à implementação do Estatuto da Metrópole. Brasília: Ipea, 2018.

FURLAN, S. A. Áreas naturais tombadas e a proteção da paisagem. Revista CPC, v. 13, n. 26 (número especial), p. 63-93, out./dez. 2018.

MENGHINI, R. P. Ecologia de manguezais: grau de perturbação e processos regenerativos em bosques de mangues da Ilha Barnabé, Baixada Santista, São Paulo, Brasil. São Paulo. 2004. Dissertação (Mestrado) - Instituto Oceanográfico, Universidade de São Paulo, São Paulo, 2004. Disponível em: <https://bit.ly/3b9mCr7>. Acesso em: 31 nov. 2019

PLANO estabelece metas até 2030. A Tribuna, Caderno Cidades, 26 fev. 2020. p. A-3.

PROJETO Inova forma grupos de análise na Baixada Santista. A Tribuna, 28 ago. 2019. Disponível em: <https://glo.bo/2XzyoHl>. Acesso em 31 out. 2019.

RIOS, L. G. Turismo de segunda residência: impasses para o desenvolvimento urbano socialmente inclusivo e ambientalmente sustentável - o caso de Bertioga, SP. 2019. Dissertação (Mestrado) - Programa de Pós-graduação Stricto Sensu em Direito Ambiental e Internacional, Universidade Católica de Santos, Santos, 2019.

SANTOS. Lei Complementar no 311, de 23 de novembro de 1998. Plano Diretor de Desenvolvimento e Expansão Urbana do Município de Santos. Diário Oficial de Santos, Santos, 25 nov. 1998.

Lei Complementar no 359, de 25 de novembro de 1999. Lei de Ordenamento do Uso e da Ocupação do Solo na Área Continental do Município. Diário Oficial de Santos, Santos, 26 nov. 1999.

Lei Complementar no 729, de 11 de julho de 2011. Lei de Ordenamento do Uso e da Ocupação do Solo na Área Continental do Município. Diário Oficial de Santos, Santos, 12 jul. $2011 \mathrm{a}$.

Lei Complementar no 730, de 11 de julho de 2011. Lei de Ordenamento do Uso e da Ocupação do Solo na Área Insular do Município. Diário Oficial de Santos, Santos, 12 jul. 2011 b.

Fundação Parque Tecnológico de Santos. Santos: Prefeitura Municipal de Santos, 2012. Disponível em: <https://is.gd/c4VSVl>. Acesso em: 2 nov. 2019.

. Lei Complementar no 821, de 27 de dezembro de 2013. Plano Diretor de Desenvolvimento e Expansão Urbana do Município de Santos. Diário Oficial de Santos, Santos, 28 dez. 2013.

Lei Complementar no 1.005 , de 16 de julho de 2018. Institui o Plano Diretor de Desenvolvimento e Expansão Urbana do Município de Santos, e dá outras providências. Diário Oficial de Santos, Santos, 17 jul. 2018a. Disponível em: <https://bit.ly/2RIiQgW>.

Lei Complementar no 1.006 , de 16 de julho de 2018. Lei de Ordenamento do Uso e da Ocupação do Solo na Área Insular. Diário Oficial de Santos, Santos, 17 jul. 2018b. Disponível em: <https://bit.ly/2REDcYi>.

Relatório 5: diretrizes para a área continental e projetos estratégicos. Santos: Prefeitura de Santos; Jaime Lerner Arquitetos Associados; Comunitas; Juntos, 2019a. 
. Santos: diretrizes preliminares para a área continental e projetos estratégicos. Santos: Prefeitura Municipal de Santos; Lerner Associados, ago. 2019b.

SANTOS, L. A. F. A influência da expansão portuária na comunidade da Ilha Diana, Santos-SP. 2015. Dissertação (Mestrado) - Programa de Pós-graduação em Sustentabilidade de Ecossistemas Marinhos, Universidade Santa Cecília, Santos, 2015.

SÁO PAULO. Secretaria de Estado do Meio Ambiente. Coordenadoria de Planejamento Ambiental. Zoneamento ecológico-econômico: setor costeiro da Baixada Santista. São Paulo: SMA, 2013.

. Resposta do SIC.SP. Protocolo 526951924765. Secretaria de Desenvolvimento Regional. São Paulo: SDR, 10 dez. 2019.

VIANA, M. A.; RIOS, L. G.; TORRES, R. J. Taus Ilha Diana: em defesa da regularização fundiária de uma comunidade caiçara em Santos. In: CONGRESSO BRASILEIRO DE DIREITO URBANÍSTICO, 9., 2017, Florianópolis, Santa Catarina. Anais... Santa Catarina: IBDU, 2017.

Disponível em: <https://bit.ly/2wMnl2M>. Acesso em: 1ํo nov. 2019. 

Ipea - Instituto de Pesquisa Econômica Aplicada

EDITORIAL

\section{Coordenação}

Reginaldo da Silva Domingos

Assistente de Coordenação

Rafael Augusto Ferreira Cardoso

\section{Supervisão}

Camilla de Miranda Mariath Gomes

Everson da Silva Moura

\section{Editoração}

Aeromilson Trajano de Mesquita

Cristiano Ferreira de Araújo

Danilo Leite de Macedo Tavares

Herllyson da Silva Souza

Jeovah Herculano Szervinsk Junior

Leonardo Hideki Higa

\section{Capa}

Danielle de Oliveira Ayres

Flaviane Dias de Sant'ana

Projeto Gráfico

Renato Rodrigues Bueno

The manuscripts in languages other than Portuguese published herein have not been proofread.

\section{Livraria Ipea}

SBS - Quadra 1 - Bloco J - Ed. BNDES, Térreo

70076-900 - Brasília - DF

Tel.: (61) 2026-5336

Correio eletrônico: livraria@ipea.gov.br 

Composto em adobe garamond pro 11,5/13,8 (texto)

Frutiger 67 bold condensed (títulos, gráficos e tabelas) Brasília-DF 



\section{Missão do Ipea}

Aprimorar as políticas públicas essenciais ao desenvolvimento brasileiro por meio da produção e disseminação de conhecimentos e da assessoria ao Estado nas suas decisões estratégicas. 